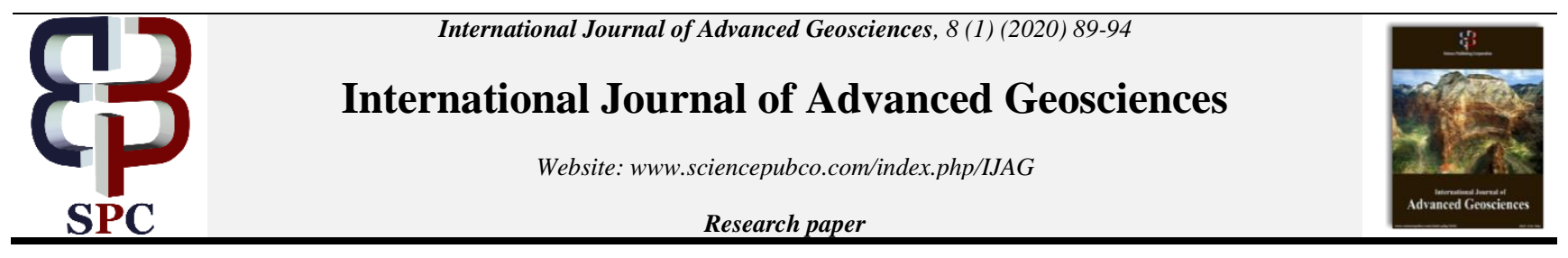

\title{
Assessment of pollution and sources of heavy metals in the sediments of the Shitalakhya river, Bangladesh
}

\author{
Kalimur Rahman 1, Saurav Barua ${ }^{2}$, Fahim Ahammad ${ }^{1}$, Md. Akramul Alam ${ }^{1}$ \\ ${ }^{1}$ Department of Civil Engineering, Dhaka University of Engineering and Technology, Gazipur, Bangladesh \\ ${ }^{2}$ Department of Civil Engineering, Daffodil International University, Dhaka, Bangladesh \\ *Corresponding author E-mail: saurav.ce@diu.edu.bd
}

\begin{abstract}
The Shitalakya River, located near Dhaka City of Bangladesh, supplies water to the city dwellers and hence it is essential to determine pollu-tion condition, ecological risk and sources of heavy metals in the river sediments. Sediment works as the sink and source of heavy metals in the riverine ecosystem. The samples collected from the ten sites of the Shitalakhya River were investigated in the study. Average concentra-tion of different heavy metals in the sediments are $\mathrm{Cu}>\mathrm{Zn}>\mathrm{Ni}>\mathrm{Pb}>\mathrm{Cr}>\mathrm{Cd}$. Geo-accumulation index reveals moderately pollute $\mathrm{Cu}$ concen-tration, unpolluted to moderately pollute $\mathrm{Ni}$ concentration and unpolluted for the rest of the heavy metals. The order of geoaccumulation index are $\mathrm{Cu}>\mathrm{Ni}>\mathrm{Pb}>\mathrm{Cd}>\mathrm{Zn}>\mathrm{Cr}$. Overall, the heavy metals render low potential ecological risk and the order of potential ecological risk index are $\mathrm{Cd}>\mathrm{Cu}>\mathrm{Ni}>\mathrm{Pb}>\mathrm{Cr}>\mathrm{Zn}$. Though the concentration of $\mathrm{Cd}$ is low in sediment, it poses higher ecological risk. Positive matrix factor-ization (PMF) identifies two sources of pollution, $\mathrm{S} 1$ and $\mathrm{S} 2$. Where, $\mathrm{S} 1$ consists with $\mathrm{Cu}, \mathrm{Ni}, \mathrm{Pb}, \mathrm{Zn}$; which come from industrial wastewater. $\mathrm{S} 2$ consists with $\mathrm{Cr}, \mathrm{Cd}, \mathrm{Pb}, \mathrm{Zn}$; which originate from natural sources. The outcomes of the study provide as a reference to plan, control and manage heavy metal pollution and protect the water source of the Shitalakhya River.
\end{abstract}

Keywords: Heavy Metal Concentration; Sediment; Ecological Risk; River Pollution; Positive Matrix Factorization.

\section{Introduction}

Heavy metals accumulate in sediment of river and they act as the reservoirs to contain heavy metal for a long time. The toxic pollutants bearing heavy metals mix with upstream water, suffer the downstream inhabitants severely. Since, large numbers of agricultural, domestic and industrial activities utilize river waters, it is essential to study river sediment quality for public health safety (Li et al. 2013, Pejman et al. 2015, Huang et al., 2020). Moreover, heavy metals accumulated in sediment and water of river form a dynamic equilibrium and are closely related to each other (Saha et al. 2001). Heavy metal in sediment are non-degradable and easily accumulate in biota. As a result, heavy metal pollution in sediment pose ecological risk due to their severe toxicity to mix with food chain and biota. Sediments of river bed act as a sink to accumulate, receive, absorb pollutants, release pollutants into water due to disturbance and therefore, consider as an important indicator of water pollution. Heavy metals, such as, $\mathrm{Pb}, \mathrm{Cd}, \mathrm{Cr}, \mathrm{Cu}, \mathrm{Ni}$ and $\mathrm{Zn}$ can accumulate in fine grained sediment easily and subsequently, carried to the river downstream (Banerjee et al. 2016).

The Shitalakhya River supplies water to the City Corporation of Dhaka. This river flowing through the Dhaka, Narayanganj and Gazipur districts and receives huge amount of waste discharges from the industries located along the river bank. These untreated industrial waste is the major sources of heavy metals and sediment pollution. The water of Shitalakhya River is highly polluted and various water quality parameters, such as, turbidity, total dissolve solid, dissolve oxygen, biochemical oxygen demand are in poor status (Rahman 2011, Islam et al. 2015, Chowdhury et al. 2015). Moreover, the water of the river is so polluted that it is unsuitable for fishes (Rahman et al. 2020). This study delved to characterize the concentration and spatial distribution of six heavy metals, i.e. $\mathrm{Pb}, \mathrm{Cr}, \mathrm{Cu}, \mathrm{Ni}, \mathrm{Cd}$ and $\mathrm{Zn}$ at ten different sites of Shitalakhya River; assess pollution status in terms of geo accumulation index ( $\mathrm{I}_{\text {geo }}$ ), potential ecological risk index (PERI) and determine the sources of heavy metal pollution using positive matrix factorization (PMF). The findings of the study reveal the geo-chemical characteristics of heavy metals and provide a guideline to control and remedy environmental pollution for the similar types of rivers.

\section{Methodology}

\subsection{Study area and sampling}

The Shitalakhya River flowing south through Gazipur and Narayanganj districts and finally meet Meghna River at Munshigang. The study area of the river is between $23^{\circ} 43^{\prime}$ to $23^{\circ} 37^{\prime} \mathrm{N}$ latitudes and $90^{\circ} 30^{\prime}$ to $90^{\circ} 32^{\prime}$ E longitudes. The sediment samples were collected from ten sites (S1-S10) in the investigated area. The sample sites were-- Shah Cement (S-1), Premier Cement (S-2), Bandar (Narayanganj) (S-3), Adamjee EPZ (S-4), ATI (S-5), Kachpur Bridge (S-6), Sinha Textile (S-7), Demra Bridge (S-8), South Rupshi (S-9) and Kanchon Bridge 
(S-10). The detail location of the sites are shown in Figure 1. The sediment samples were collected through Ekman grab sampler (Figure 2) from top $30 \mathrm{~cm}$ from riverbed on 18 January, 2019.

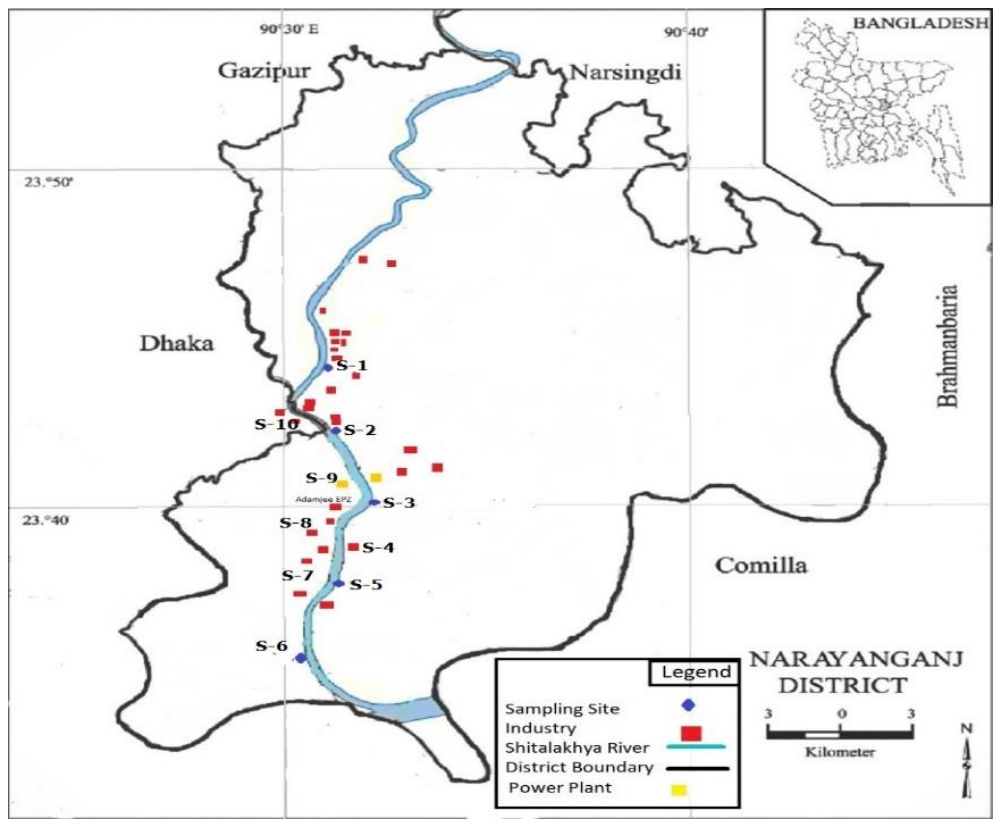

Fig. 1: Location of Sampling Sites Along the Shitalakhya River Shown in Map.

(A)

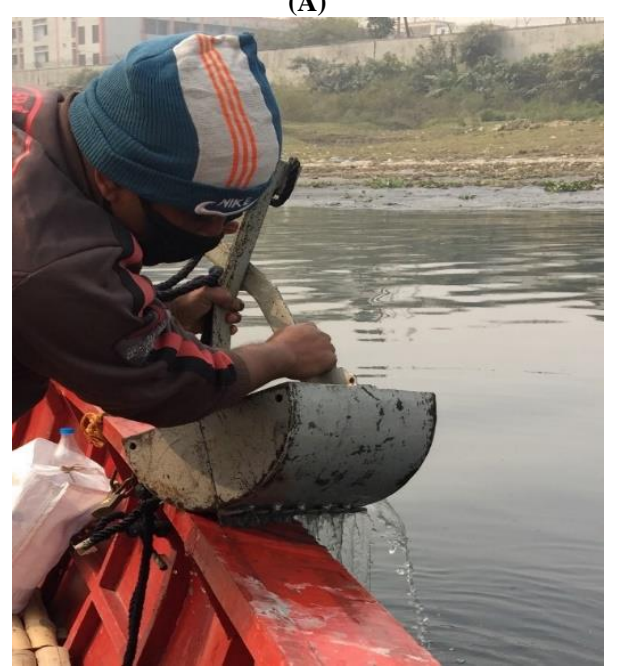

(B)

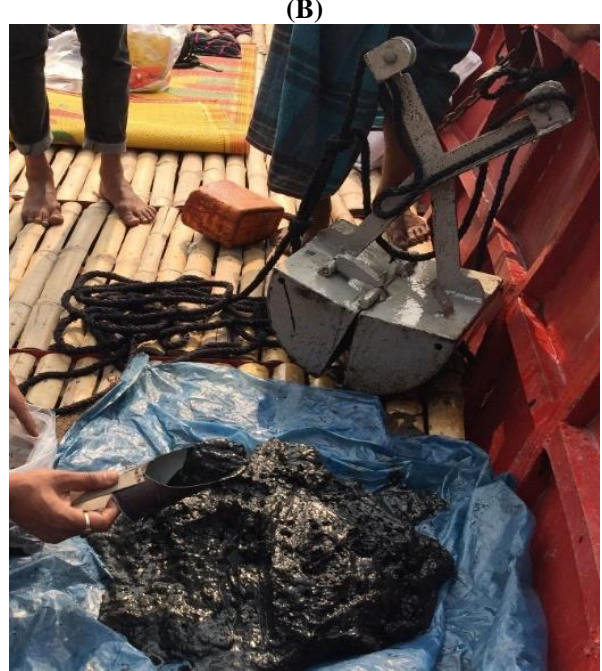

Fig. 2: Photographs of Field Sampling (A) Ekman Grab Sampler and (C) Fresh Sediments Collected by the Sampler.

\subsection{Sample digestion and analysis}

The collected samples were processed for digestion before analyzing using Atomic Absorption Spectrophotometry (AAS). The samples were placed in acid washed container and over dry at $105^{\circ} \mathrm{C}$ for $24 \mathrm{hr}$. Then the sediment were separated by large sieve in order to remove stone and pebbles. The sediments were crushed by acid washed pestle and separated by No. 50 sieve. Then $5 \mathrm{gm}$ of sieved sediment were collect and transferred to an acid-washed volumetric flask and added $100 \mathrm{ml}$ of distilled water. After that, $7.5 \mathrm{ml}$ concentrated hydrochloric acid and $2.5 \mathrm{ml}$ concentrated nitric acid were mixed into the volumetric flask and the flask covered with a watch glass. The sample then heated at $200^{\circ} \mathrm{C}$ for $1 \mathrm{hr}$. After the samples had cooled to room temperature; those were stirred for 5 minutes and filtered $(0.45 \mu \mathrm{m})$ by a glass funnel containing Whatttman No.1 filter paper. The reaction vessels and watch glasses were rinsed with distilled water thoroughly. The filtrate was reserved in a glass bottle for the analysis of metals. Then AAS were calibration by 0.2, 0.5, 2, 5 PPM stock solutions. After that, the analysis were performed by AAS attached with a graphite furnace to determination of metal concentrations within the samples. Atomic Absorption Spectrophotometry (model: Shimadzu, AA-7000) at the Environmental Engineering Laboratory of Dhaka university of Engineering and Technology was used to measure the heavy metal concentration in the sediment samples.

\subsection{Pollution assessment of sediment}

\subsubsection{Geo-accumulation index}

Geo-accumulation index ( $\mathrm{I}_{\mathrm{geo}}$ ), formulated by Muller (1979) illustrates the enrichment of heavy metals in the sediment. It is calculated as follows: 
Where, $\mathrm{C}_{\mathrm{s}}=$ concentration of heavy metal in sediment sample $(\mathrm{mg} / \mathrm{kg}), \mathrm{C}_{\mathrm{b}}=$ geochemical background concentration of heavy $\mathrm{metal}(\mathrm{mg} / \mathrm{kg})$. 1.5 is correction factor. In this study, we have used Toxic rating value (TRV) as background concentration (USEPA 1999). Igeo classified the sediment pollution into following categories: Class 0 stands for unpolluted (Igeo $\leq 0$ ), Class 1 stands for unpolluted to moderately polluted $(0<$ Igeo $\leq 1)$, Class 2 stands for moderately polluted $\left(1<\right.$ Igeo $\left._{1} \leq 2\right)$, Class 3 stands for moderate to heavily polluted $(2<$ Igeo $\leq 3)$, Class 4 stands for heavily polluted $(3<$ Igeo $\leq 4)$, Class 5 stands for heavy to extremely polluted $(4<$ Igeo $\leq 5)$ and Class 6 stands for extremely polluted ( $\mathrm{I}_{\mathrm{geo}}>5$ ).

\subsubsection{Pollution ecological risk index}

The pollution ecological risk index (PERI), introduced by Hakanson (1980) quantifies the ecological risk of heavy metals in sediment. The PERI is expressed as:

$$
\mathrm{E}_{\mathrm{r}}^{\mathrm{i}}=\mathrm{T}_{\mathrm{r}}^{\mathrm{i}} \times_{C_{\mathrm{b}}}^{C_{c_{x}}}
$$

PERI $=\sum E_{r}^{i_{r}}$

Where, $\mathrm{E}_{\mathrm{r}}^{\mathrm{i}}=$ potential ecological risk factor, $\mathrm{T}_{\mathrm{r}}^{\mathrm{i}}=$ toxic response factor. $\mathrm{T}_{\mathrm{r}}^{\mathrm{i}}$ value for $\mathrm{Pb}, \mathrm{Cr}, \mathrm{Cu}, \mathrm{Ni}, \mathrm{Cd}$ and $\mathrm{Zn}$ are $5,2,5,5,30$ and 1 respectively. $\mathrm{E}_{\mathrm{r}}^{\mathrm{i}}<40$ represents low, $40 \leq \mathrm{E}_{\mathrm{r}}^{\mathrm{i}}<80$ represents moderate, $80 \leq \mathrm{E}_{\mathrm{r}} \mathrm{i}_{1}<160$ represents considerable, $160 \leq \mathrm{E}_{\mathrm{r}}^{\mathrm{i}}<320$ represents high and $\mathrm{E}_{\mathrm{r}}^{\mathrm{i}}>320$ represents very high. PERI $<150$ represents low, $150 \leq \mathrm{PERI}<300$ represents moderate, $300 \leq \mathrm{PERI}<600$ represents considerable and PERI $\geq 600$ represents high.

\subsubsection{Positive matrix factorization}

The positive matrix factorization is a receptor modeling technique to determine the sources of heavy metals in sediments. We have used EPA PMF v. 5.0 software (USEPA 2014) developed by USEPA for source apportionment in the study.

\section{Results and discussion}

\subsection{Spatial distribution of heavy metals}

In this study, the acceptable heavy metal concentration in sediments were considered as per Toxicity reference value (TRV) and USEPA sediment standards (USEPA 1999). The Pb concentration in sediment sample was high at S-1 (Shah Cement) site exceeded USEPA sediment standards and slightly high at S-5 (ATI) site, exceeding TRV. Cr concentration in samples were within 4.14-17.64 mg/kg, which were far below pollution limit and safe. Cu concentrations were high in most of the sites and maximum (130.02 mg/kg) at S-4 (Adamjee EPZ). Ni concentration in sediment were high at S-9 (Kachpur Bridge), S-4 (Adamjee EPZ) sites and USEPA and TRV recommended values. $\mathrm{Cd}$ concentration in sediments were ranges from $0.18-0.59 \mathrm{mg} / \mathrm{kg}$. Zn concentration were almost uniform in all sites ranging 48.71-53.30 $\mathrm{mg} / \mathrm{kg}$. The descending order of average heavy metal concentration was $\mathrm{Cu}>\mathrm{Zn}>\mathrm{Ni}>\mathrm{Pb}>\mathrm{Cr}>\mathrm{Cd}$. $\mathrm{Cu}$ concentration was maximum in the sediment samples.

Table 1: Concentration of Heavy Metal $(\mathrm{Mg} / \mathrm{Kg})$ in Sediment Samples of Various Locations in the Shitalakhya River

\begin{tabular}{|c|c|c|c|c|c|c|}
\hline Site & $\mathrm{Pb}$ & $\mathrm{Cr}$ & $\mathrm{Cu}$ & $\mathrm{Ni}$ & $\mathrm{Cd}$ & $\mathrm{Zn}$ \\
\hline S-1 & 40.24 & 8.42 & 48.50 & 29.21 & 0.41 & 50.65 \\
\hline $\mathrm{S}-2$ & 19.74 & 13.78 & 20.73 & 18.33 & 0.56 & 48.95 \\
\hline S-3 & 24.24 & 10.84 & 25.43 & 23.10 & 0.59 & 48.71 \\
\hline S-4 & 19.44 & 17.64 & 130.02 & 35.50 & 0.39 & 52.55 \\
\hline S-5 & 31.42 & 11.38 & 46.22 & 26.81 & 0.43 & 51.09 \\
\hline S-6 & 28.42 & 8.52 & 63.04 & 32.64 & 0.23 & 52.91 \\
\hline S-7 & 21.30 & 7.62 & 42.80 & 27.54 & 0.46 & 50.70 \\
\hline S-8 & 20.02 & 4.14 & 70.70 & 31.28 & 0.18 & 53.30 \\
\hline S-9 & 20.24 & 11.34 & 49.22 & 36.90 & 0.50 & 51.74 \\
\hline S-10 & 21.56 & 7.78 & 47.77 & 29.61 & 0.50 & 50.37 \\
\hline Average & 24.66 & 10.15 & 54.44 & 29.09 & 0.43 & 51.10 \\
\hline Range & $19.44-40.24$ & $4.14-17.64$ & $20.73-130.02$ & $18.33-36.90$ & $0.18-0.59$ & $48.71-53.30$ \\
\hline TRV & 31.00 & 26.00 & 16.00 & 16.00 & 0.60 & 110.00 \\
\hline USEPA & 35.80 & 43.40 & 31.60 & 22.70 & 0.99 & 121.00 \\
\hline
\end{tabular}

(A) 


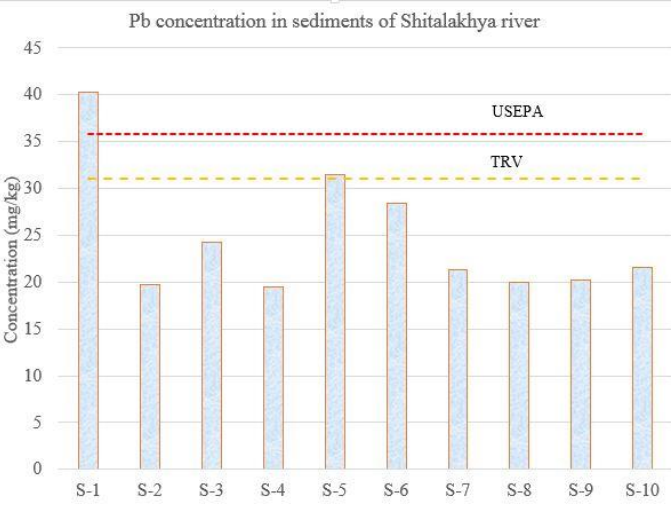

(C)

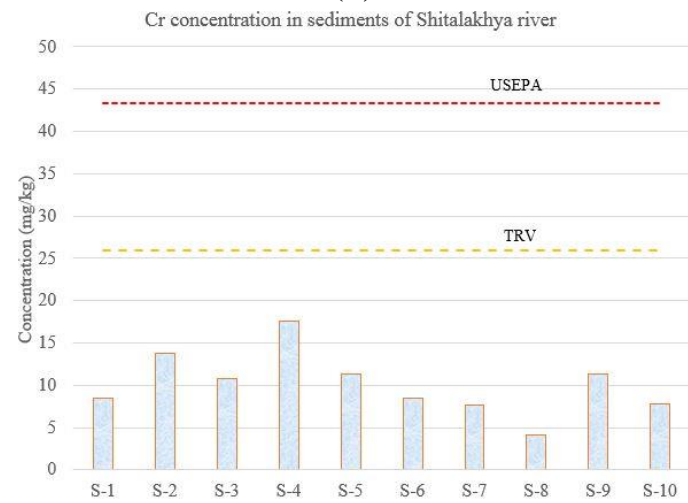

(E)

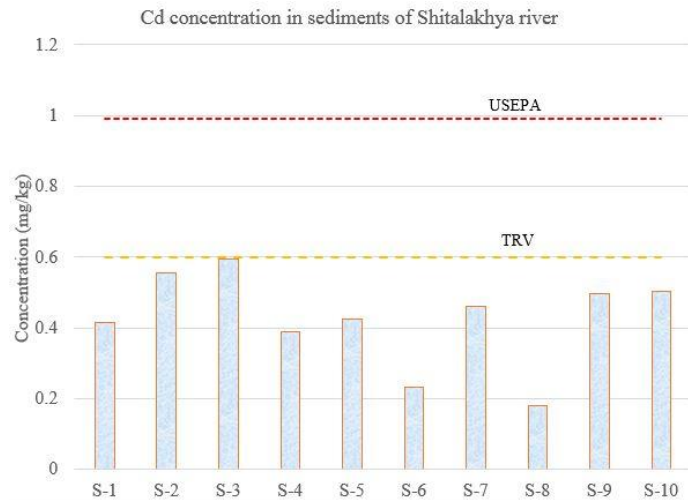

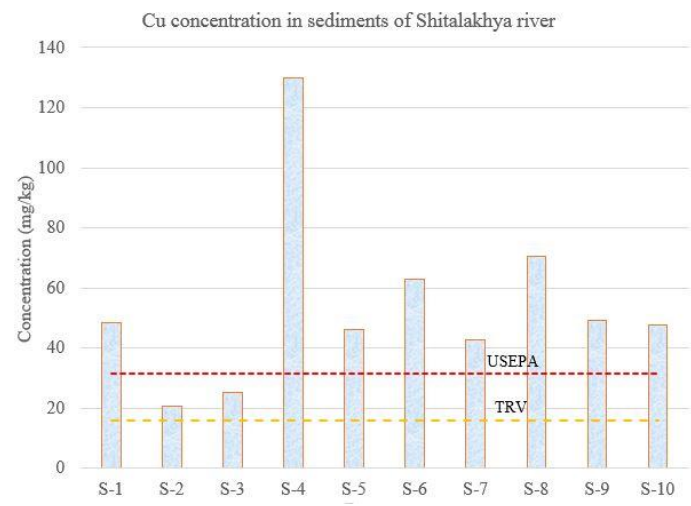

(D)

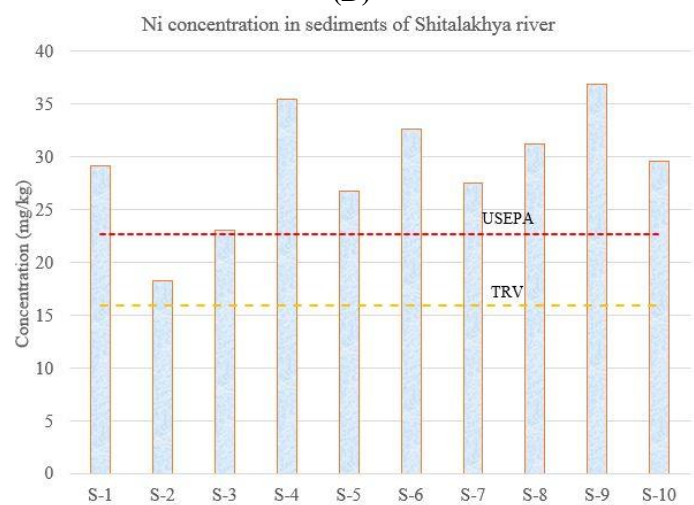

(F)

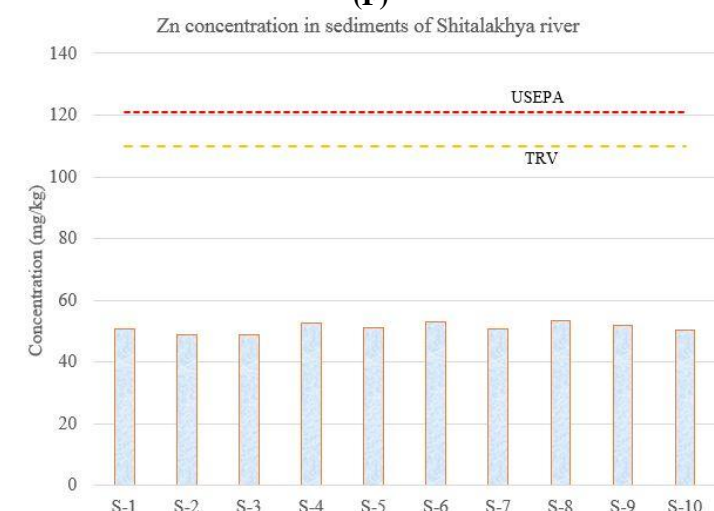

Fig. 3: Spatial Distribution of Heavy Metal (A) $\mathrm{Pb},(\mathrm{B}) \mathrm{Cu}$, (C) Cr, (D) Ni, (E) Cd and (F) Zn in Sediments at Different Sites of Shitalakhya River.

\subsection{Assessment of geo-accumulation index}

Considering average Igeo, $\mathrm{Cu}$ concentration was moderately polluted and $\mathrm{Ni}$ concentration was unpolluted to moderately pollute in the sediment samples. S-4 (Adamjee EPZ) site had heavy polluted Cu concentration. Overall, most of the sediments in the sites were unpolluted

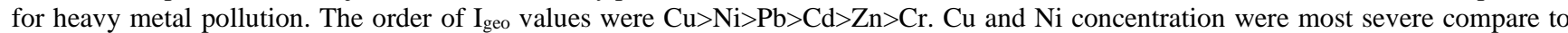
other heavy metals.

Table 2: $\mathrm{I}_{\mathrm{geo}}$ Values Calculated for Different Sites of Shitalakhya River

\begin{tabular}{|c|c|c|c|c|c|c|}
\hline Site & $\mathrm{Pb}$ & $\mathrm{Cr}$ & $\mathrm{Cu}$ & $\mathrm{Ni}$ & $\mathrm{Cd}$ & $\mathrm{Zn}$ \\
\hline S-1 & -0.21 & -2.21 & $1.01 * *$ & $0.28 *$ & -1.12 & -1.70 \\
\hline S-2 & -1.24 & -1.50 & -0.21 & -0.39 & -0.69 & -1.75 \\
\hline S-3 & -0.94 & -1.85 & $0.08^{*}$ & -0.06 & -0.60 & -1.76 \\
\hline S-4 & -1.26 & -1.14 & $2.44 * * *$ & $0.56^{*}$ & -1.21 & -1.65 \\
\hline S-5 & -0.57 & -1.78 & $0.95^{*}$ & $0.16^{*}$ & -1.08 & -1.69 \\
\hline S-6 & -0.71 & -2.19 & $1.39 * *$ & $0.44 *$ & -1.96 & -1.64 \\
\hline S-7 & -1.13 & -2.36 & $0.83^{*}$ & $0.20 *$ & -0.96 & -1.70 \\
\hline S-8 & -1.22 & -3.24 & $1.56^{* *}$ & $0.38 *$ & -2.32 & -1.63 \\
\hline S-9 & -1.20 & -1.78 & $1.04 * *$ & $0.62 *$ & -0.86 & -1.67 \\
\hline S-10 & -1.11 & -2.33 & $0.99^{*}$ & $0.30 *$ & -0.84 & -1.71 \\
\hline Average & -0.96 & -2.04 & $1.01 * *$ & $0.25^{*}$ & -1.16 & -1.69 \\
\hline
\end{tabular}

NB: *** represents moderate to heavily polluted, $* *$ represents moderately polluted and *represents unpolluted to moderately polluted.

\subsection{Assessment of PERI}


Potential ecological risk index (PERI) value $<150$ for all sites, hence the risk was low. In addition, level of single metal pollution risk factor $\left(E_{r}^{i}\right)<40$ for all heavy metals in the sediment samples, hence the risk factor is low also. The descending order of PERI values were $\mathrm{Cd}>\mathrm{Cu}>\mathrm{Ni}>\mathrm{Pb}>\mathrm{Cr}>\mathrm{Zn}$. Although, concentration of $\mathrm{Cd}$ was low, it posed more ecological threat compare to other heavy metals in the sediments.

Table 3: PERI Value and Pollution Risk Factor $\left(\mathrm{E}_{\mathrm{r}}^{\mathrm{i}}\right)$ Value for Different Sites of Shitalakhya River

\begin{tabular}{|c|c|c|c|c|c|c|c|}
\hline Sites & $\mathrm{Pb}$ & $\mathrm{Cr}$ & $\mathrm{Cu}$ & $\mathrm{Ni}$ & $\mathrm{Cd}$ & $\mathrm{Zn}$ & PERI \\
\hline S-1 & 6.5 & 0.6 & 9.1 & 9.1 & 20.7 & 0.5 & 46.5 \\
\hline S-2 & 3.2 & 1.1 & 3.9 & 5.7 & 27.8 & 0.4 & 42.1 \\
\hline S-3 & 3.9 & 0.8 & 4.8 & 7.2 & 29.7 & 0.4 & 46.9 \\
\hline S-4 & 3.1 & 1.4 & 24.4 & 11.1 & 19.4 & 0.5 & 59.8 \\
\hline S-5 & 5.1 & 0.9 & 8.7 & 8.4 & 21.3 & 0.5 & 44.8 \\
\hline S-6 & 4.6 & 0.7 & 11.8 & 10.2 & 11.6 & 0.5 & 39.3 \\
\hline S-7 & 3.4 & 0.6 & 8.0 & 8.6 & 23.1 & 0.5 & 44.2 \\
\hline S-8 & 3.2 & 0.3 & 13.3 & 9.8 & 9.0 & 0.5 & 36.1 \\
\hline S-9 & 3.3 & 0.9 & 9.2 & 11.5 & 24.8 & 0.5 & 50.2 \\
\hline S-10 & 3.5 & 0.6 & 9.0 & 9.3 & 25.2 & 0.5 & 47.9 \\
\hline Average & 4.0 & 0.8 & 10.2 & 9.1 & 21.3 & 0.5 & 45.8 \\
\hline
\end{tabular}

\subsection{Identifying sources of heavy metals}

Positive matrix factorization (PMF) determines two sources of heavy metal in sediment of Shitalakhya River. The S-1 source comprised with $\mathrm{Cu}, \mathrm{Ni}, \mathrm{Pb}, \mathrm{Zn}$ and the $\mathrm{S}-2$ source comprised with $\mathrm{Cr}, \mathrm{Cd}, \mathrm{Pb}$ and $\mathrm{Zn}$ (Figure 4). S-1 originated from industrial waste and $\mathrm{S}-2 \mathrm{came}$ from natural sources. $\mathrm{Pb}$ and $\mathrm{Zn}$ contributed to both sources almost equally (Figure 5).

Table 4: Factor Profiles of Heavy Metal Concentration Obtained from PMF

\begin{tabular}{llllll}
\hline \multirow{2}{*}{ Heavy metals } & \multicolumn{2}{l}{ Factor Profiles (conc. of species) } & \multicolumn{2}{l}{ Factor Profiles (\% of species sum) } & \multicolumn{2}{c}{ Factor Profiles (\% of factor total) } & S-2 & S-1 \\
& $\mathrm{S}-1$ & $\mathrm{~S}-2$ & $\mathrm{~S}-1$ & 55.28 & 10.45 \\
$\mathrm{~Pb}$ & 10.18 & 12.58 & 44.72 & 72.91 & 2.57 \\
$\mathrm{Cr}$ & 2.51 & 6.75 & 27.09 & 17.95 & 19.36 \\
$\mathrm{Cu}$ & 41.37 & 9.05 & 82.05 & 37.29 & 42.45 \\
$\mathrm{Ni}$ & 18.02 & 10.72 & 62.71 & 80.23 & 18.49 \\
$\mathrm{Cd}$ & 0.08 & 0.33 & 19.77 & 50.29 & 0.08 \\
$\mathrm{Zn}$ & 25.29 & 25.59 & 49.71 & & 13.92 \\
\hline
\end{tabular}

$82.05 \%$ of total $\mathrm{Cu}$ concentration and $62.71 \%$ of total $\mathrm{Ni}$ concentration originated from industrial waste (S-1). $72.91 \%$ of total $\mathrm{Cr}$ concentration and $80.23 \%$ of total Cd concentration originated from natural sources (S-2).

(A)

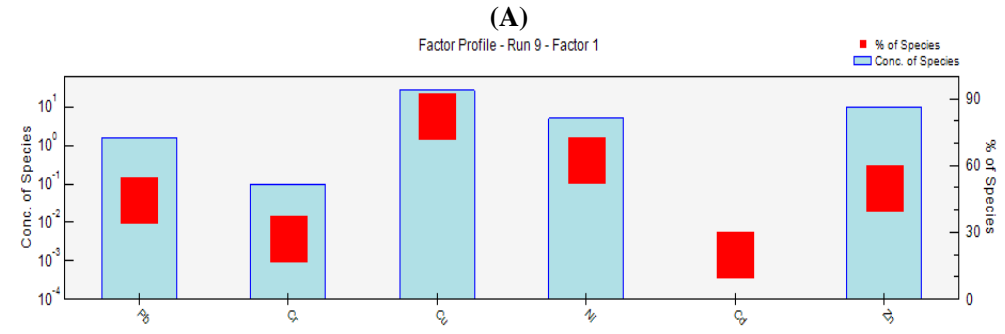

(B)

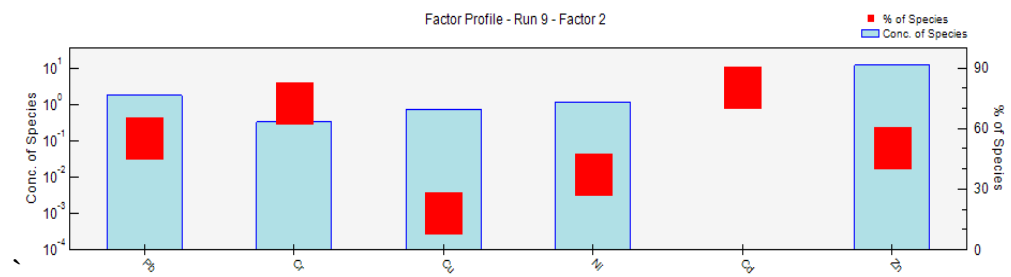

Fig. 4: Factor Profile of (A) S-1 and (B) S-2 Sources in the Sediments of Shitalakhya River.

Industrial waste (S-1) consisted with $42.45 \% \mathrm{Cu}$ concentration and natural source (S-2) consisted with $39.35 \% \mathrm{Zn}$. 


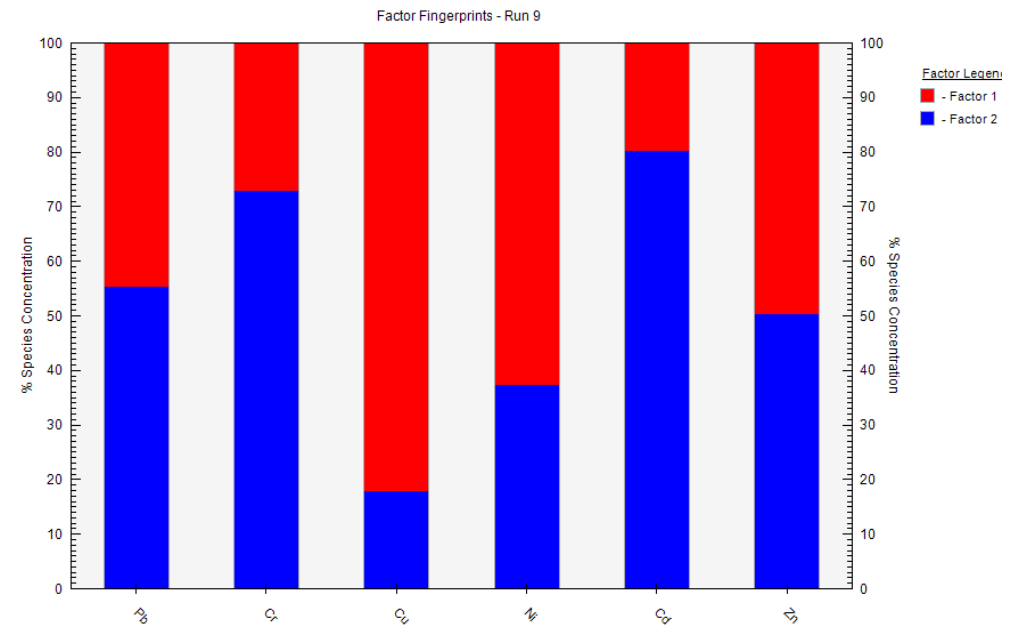

Fig. 5: Factor Figure-Prints of S-1 And S-2 Sources of the Sediments of Shitalakhya River.

\section{Conclusion}

Heavy metal pollution in river sediment have severe environmental impact on riverine ecosystem. The study investigates six heavy metals in the sediment of Shitalakhya River, Bangladesh. The heavy metal concentration measured at the sampling sites pose low ecological threat to human health. However, some locations such as, S-4 (Adamjee EPZ) had moderate to heavily polluted concentration, which require special attention. Overall, $\mathrm{Cu}$ concentration was found moderately polluted and $\mathrm{Ni}$ concentration was found unpolluted to moderate polluted. The average concentration of heavy metals in the descending order of $\mathrm{Cu}>\mathrm{Zn}>\mathrm{Ni}>\mathrm{Pb}>\mathrm{Cr}>\mathrm{Cd}$. Cd concentration was very small in quantity, however it had most ecological risk potential. Careful monitoring and remedial plan need to be develop to keep heavy metal concentration within USEPA sediment standards and toxicity reference index.

The study can be extended for the ecological risk assessment of heavy metal in sediments for the river with similar geomorphological features and surroundings. Influence of various physical and chemical factors, such as, $\mathrm{pH}$, turbidity, temperature, concentration of solute, composition, water chemistry on the heavy metal decomposition in the sediment can be investigated. Besides, effects of organic matter content and grain size distribution on heavy metal concentration can also be studied. The proposed source identification technique PMF can be implemented for other rivers as well.

\section{Acknowledgment}

The authors would like to acknowledge Department of Civil Engineering, Dhaka University of Engineering and Technology (DUET) for providing funds to conduct this research.

\section{References}

[1] Banerjee S, Kumar A, Maiti SK and Chowdhury A (2016) Seasonal variation in heavy metal contaminations in water and sediments of Jamshedpur stretch of Subarnarekha river, India. Environmental earth sciences, 75, 3, 265. https://doi.org/10.1007/s12665-015-4990-6.

[2] Chowdhury RM, Ankon AA and Bhuiyan MK (2020) Water Quality Index (WQI) of Shitalakshya River near Haripur Power Station, Narayanganj, Bangladesh, 7-9 February 2020. Proceedings of the 5th International Conference on Civil Engineering for Sustainable Development (ICCESD 2020), KUET, Khulna, Bangladesh (ISBN-978-984-34-8764-3).

[3] Hakanson L (1980) An Ecological Risk Index for Aquatic Pollution Control. A Sedimentological Approach, Water Res. 14, 975-1001 https://doi.org/10.1016/0043-1354(80)90143-8.

[4] Huang Z, Liu C, Zhao X, Dong J and Zheng B (2020) Risk assessment of heavy metals in the surface sediment at the drinking water source of the Xiangjiang River in South China. Environmental Sciences Europe, 32, 1, 1-9. https://doi.org/10.1186/s12302-020-00305-w.

[5] Islam JB, Sarkar M, Rahman AL and Ahmed KS (2015) Quantitative assessment of toxicity in the Shitalakkhya River, Bangladesh. The Egyptian Journal of Aquatic Research, 41, 1, 25-30. https://doi.org/10.1016/j.ejar.2015.02.002.

[6] Li X, Wang Y, Li B, Feng C, Chen Y and Shen Z (2013) Distribution and speciation of heavy metals in surface sediments from the Yangtze estuary and coastal areas. Environmental earth sciences, 69, 5, 1537-1547. https://doi.org/10.1007/s12665-012-1988-1.

[7] Muller G (1979) Heavy Metals in the Sediment of the Rhine-changesseity, Umsch. Wiss. Tech. 79, 778-783.

[8] Pejman A, Bidhendi GN, Ardestani M, Saeedi M and Baghvand A (2015) A new index for assessing heavy metals contamination in sediments: a case study. Ecological indicators, 58, 365-373. https://doi.org/10.1016/j.ecolind.2015.06.012.

[9] Rahman MK (2011) Assessment of heavy metal contamination of sediments of some polluted rivers, M.Sc. Thesis, Bangladesh University of Engineering and Technology.

[10] Rahman MB, Islam MM, Ruma M and Rahman MM (2020) Effects of Environmental Condition on Spatial-temporal Changes of Fish Diversity and Morphology of Shitalakshya River. Ecologia, 10, 1, 38-49. https://doi.org/10.3923/ecologia.2020.38.49.

[11] Saha SB, Mitra A, Bhattacharyya SB and Choudhury A (2001) Status of sediment with special reference to heavy metal pollution of a brackishwater tidal ecosystem in northern Sundarbans of West Bengal. Tropical Ecology, 42, 1, 127-132.

[12] USEPA (2014) EPA Positive Matrix Factorization (PMF) 5.0 Fundamentals and User Guide, United States Environmental Protection Agency, Washington, DC, USA.

[13] USEPA (1999) National recommended water quality criteria correction United State Environmental Protection Agency EPA 822-Z-99-001, 25. (http://www.epa.gov./ostwater/pci/revcom). 